\title{
Off-Grid Solar PV Power Generation System in Sindh, Pakistan: A Techno-Economic Feasibility Analysis
}

\author{
Li Xu ${ }^{1,2}$, Ying Wang ${ }^{1}$, Yasir Ahmed Solangi ${ }^{1, * \mathbb{C}}$, Hashim Zameer ${ }^{1}$ and Syed Ahsan Ali Shah ${ }^{1}$ \\ 1 College of Economics and Management, Nanjing University of Aeronautics and Astronautics, \\ Nanjing 211106, China; shirley.xu@nuaa.edu.cn (L.X.); yingwang@nuaa.edu.cn (Y.W.); \\ hashimzameer@nuaa.edu.cn (H.Z.); ahsan.shah1@hotmail.com (S.A.A.S.) \\ 2 College of Finance, Jiangsu Vocational Institute of Commerce, Nanjing 211168, China \\ * Correspondence: yasir.solangi86@hotmail.com; Tel.: +86-186-5185-2672
}

Received: 6 April 2019; Accepted: 17 May 2019; Published: 22 May 2019

\begin{abstract}
The off-grid solar photovoltaic (PV) system is a significant step towards electrification in the remote rural regions, and it is the most convenient and easy to install technology. However, the strategic problem is in identifying the potential of solar energy and the economic viability in particular regions. This study, therefore, addresses this problem by evaluating the solar energy potential and economic viability for the remote rural regions of the Sindh province, Pakistan. The results recommended that the rural regions of Sindh have suitable solar irradiance to generate electricity. An appropriate tilt angle has been computed for the selected rural regions, which significantly enhances the generation capacity of solar energy. Moreover, economic viability has been undertaken in this study and it was revealed that the off-grid solar PV power generation system provides electricity at the cost of Pakistani Rupees (PKR) 6.87/kWh and is regarded as much cheaper than conventional energy sources, i.e., around PKR 20.79/kWh. Besides, the off-grid solar PV power generation system could mitigate maximum $\mathrm{CO}_{2}$ annually on the condition that all of the selected remote rural regions adopt the off-grid solar PV system. Therefore, this study shall help the government to utilize the off-grid solar PV power generation system in the remote rural regions of Pakistan.
\end{abstract}

Keywords: off-grid Solar PV power generation; remote rural regions; economic feasibility; $\mathrm{CO}_{2}$ mitigation; Pakistan

\section{Introduction}

Electricity is the main source for economic, environmental, and social growth of any country. Electricity is considered to be an ideal invention of humankind and has brought a lot of changes in human lives and society. Nevertheless, approximately 1.1 billion people of the earth are suffering or living without electricity [1]. The majority of the population suffering from this situation are located in rural areas of South-Asia and Sub-Saharan Africa [2]. Similarly, a large proportion of Pakistan are living in rural regions, and the majority of them do not have access to electricity. Pakistan is a developing country facing economic, environmental, and social development challenges which have led the country to an increased power demand. The country's total power demand is 25,000 Megawatts (MW) and this is estimated to be boosted up 40,000 MW by 2030 [3]. Whereas, the electricity supply remains around 17,000 MW, causing an electricity shortage of $8000 \mathrm{MW}$ in the country [4]. In the results, the electricity shortfalls in both urban and rural areas around 12 to $18 \mathrm{~h}$ a day [5]. Furthermore, the condition of the remote rural regions of Sindh is very bad, where electricity remains inaccessible for many days.

Pakistan is enriched with a vast potential of energy sources such as oil, gas, coal, and renewable energy (i.e., solar, wind, hydro, and biomass). The estimated potential to generate electricity from 
solar energy is 2900 Gigawatts (GW), wind energy (346 GW), hydropower (6 GW), and biomass energy (5 GW) [6]. The province of Sindh is also enriched with renewable energy (RE) sources and the government needs to tap RE to generate electricity [7]. However, most of the rural regions do not have an electricity facility. Forty-eight percent of the population of the Sindh province are living in rural regions, and approximately 13,451 villages are un-electrified [8]. These villages are scattered near and far from the on-grid station, thus connecting to the grid is uneconomic and expensive. The demand for electricity in the rural regions is low when compared to urban areas, from only 50 to 100 Watts (W) per household [9]. Only a small number of lights and one to two fans are required in rural houses because each house is very small and generally built with one room. Providing on-grid transmission to these villages for such a minimum load is expensive and therefore, there is a very minimum chance of grid-connected electricity in the near future. Likewise, electricity generated from diesel generators does not propose an economical option because it is difficult to transport oil to remote rural regions, as well as ineffective for the environment. Pakistan has a structured energy sector for both international and local stakeholders. Moreover, the stakeholders are unwilling to invest in and participate in $\mathrm{RE}$ technologies due to high-investment cost, high-discount rates, short-back period requirements, the lack of infrastructural conditions, remoteness regions, and unavailability of the specific region's potential [10]. Currently, due to the worsening economic condition in Pakistan, the government has also called to shut-down all of the on-going RE projects in the Sindh and the Khyber Pakhtunkhwa (KPK) provinces, and this decision negatively affects the development of RE sources and over three billion dollars in investments [11]. The province of Sindh suffers the most from this government decision as its 53 projects are in-progress.

On the above-stated factors, the off-grid solar energy is the best option to generate electricity for rural regions of the province. The regions of the Sindh province receive a high amount of solar radiance throughout the year [12]. The province has enormous potential for solar energy and receives high solar irradiation, with more than 300 sunlight days with about $1800-2200 \mathrm{kWh} / \mathrm{m}^{2}$ annual global horizontal irradiation [13]. Furthermore, the Asian Development Bank recommended that the off-grid solar photovoltaic (PV) is the best option, as it is easy to install, low-cost, and increases the socio-economic conditions of the rural regions [9,14]. Various studies have proposed the off-grid solar PV system solution to provide electricity in the rural regions $[15,16]$. Moreover, solar PV evades extra costs, fuel transportation, and makes the project simple by installing on-site resources. In reference [17], it was presented that off-grid solar PV is an appropriate and sustainable choice for rural electrification due to its life-cycle cost, net energy, and local environmental benefits. In another study [18], the authors identified that the development of the solar PV system improves the living standard of the people and also increases the economic and social conditions in the region. The solar PV system is very favorable for the environment because it has no noise impact, mitigates $\mathrm{CO}_{2}$ emissions, and does not harm human health [19]. Moreover, numerous other studies, such as [20-22], have presented that the off-grid solar PV system is a significant application for electrification and is an economically viable option for the rural regions. In the US, the residential sector has built energy consumption-related heating and air-conditioning, which make-up of a total of $42 \%$ of a buildings total energy use [23]. In another study, the authors have assessed the wind energy potential to generate renewable hydrogen energy in the Sindh province [24]. The planning is the most important aspect for energy management and sustainable development, such as social, environmental, and economic [25].

For achieving the target of providing electricity to rural regions, there should be the proper policies implemented for solar PV power generation system. Extensive research is required to evaluate the particular regions for identifying solar energy potential, as well as to assess the economic viability of the regions. To the best of the authors' knowledge, no such research has been conducted for the Sindh province. Thus, this study aims to fill this research gap. In the study, five rural regions of the Sindh province, i.e., Panoaqil, Badin, Nawabshah, Mirpurkhas, and Kambar, are undertaken to investigate the solar energy potential for electricity generation. The main objectives of the study are: 
- To evaluate the techno-economic feasibility of an off-grid solar PV system of five regions of Sindh

- To electrify the above-mentioned rural regions by an off-grid solar PV system

Therefore, this study shall help policy and decision-makers to establish solar PV power generation system rural programs in Sindh and also support unwilling stakeholders to invest by providing comprehensive techno-economic analysis. This study is a way forward for developing off-grid solar PV system in the rural regions of Sindh, Pakistan.

\section{Electricity Background in Sindh Province}

Sindh is the third largest province by area, and the second largest in terms of the population in Pakistan [26]. The location of the Sindh province holds strategic importance due to its long coastal line, as presented in Figure 1. The Karachi port also provides the best, most economical, and shortest route to the neighboring countries for transferring cargo. The geographical location of the port is very significant, thus it has attracted foreign investment, development projects, and overall contributes to both business and economic growth [27]. Therefore, the on-going projects have rapidly increased the electricity demand in Sindh.

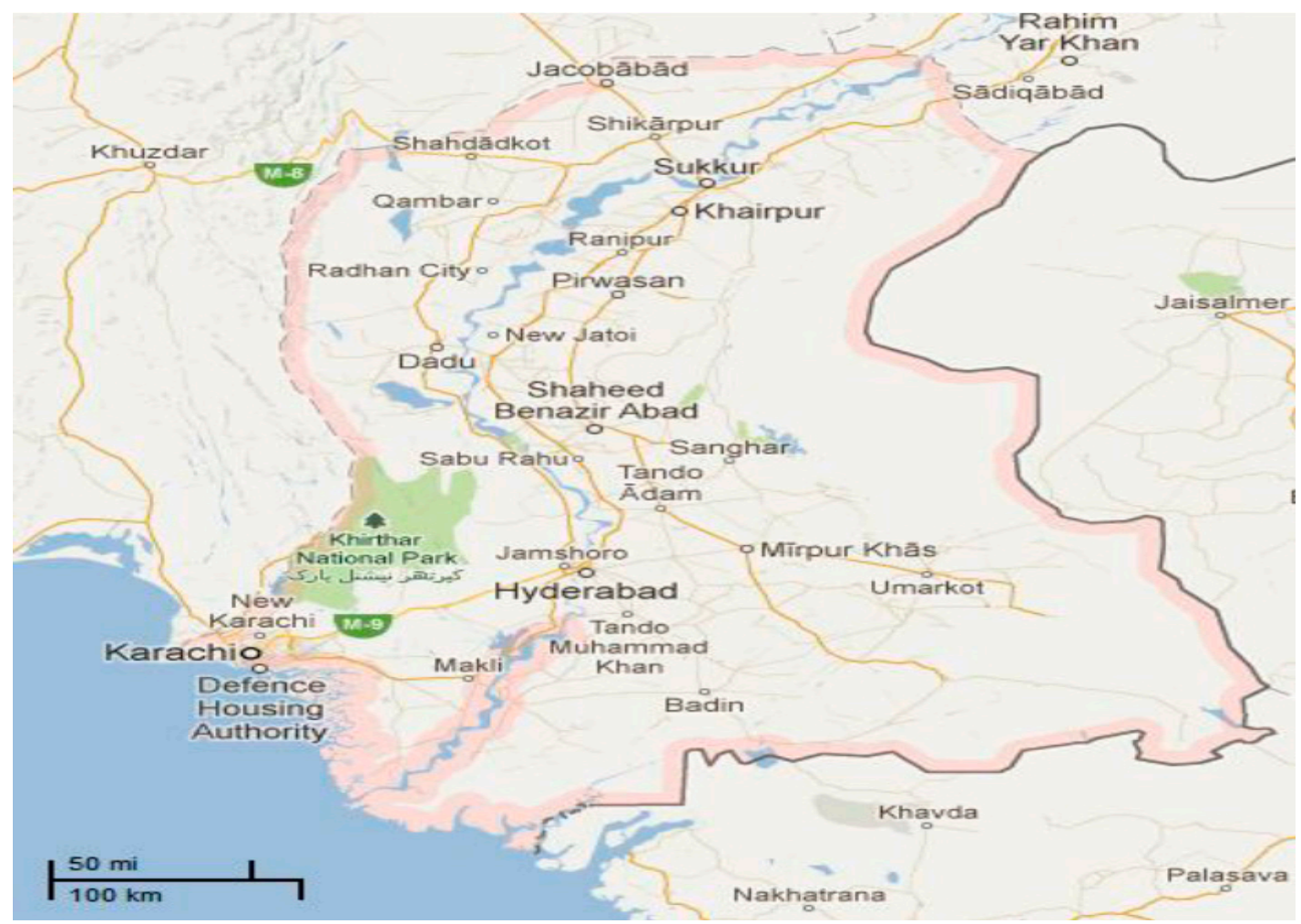

Figure 1. Sindh province map [28].

The energy demand is increasing day by day, which results in a huge electricity shortfall in the country [29]. The Sindh province is being the most affected by the increasing electricity deficit as they face a fresh series of load-shedding between 2 to $17 \mathrm{~h}$ a day [30]. This situation is even worse in remote rural regions of Sindh, where power is inaccessible for many days. Moreover, the electricity consumption in the rural regions is considered very low, and the transmission lines are a long distance from the rural areas. Thus, it is considered as cost-intensive.

Pakistan has an estimated 2900 GW solar energy potential, however, this renewable source is still waiting to be harnessed [31]. Figure 2 presented the major share in the electricity generation comprised of the gas of $33.6 \%$, oil $32.1 \%$, hydropower $26.1 \%$, nuclear $5.7 \%$, renewable energy $2.2 \%$, and coal $0.2 \%$, respectively [32]. 


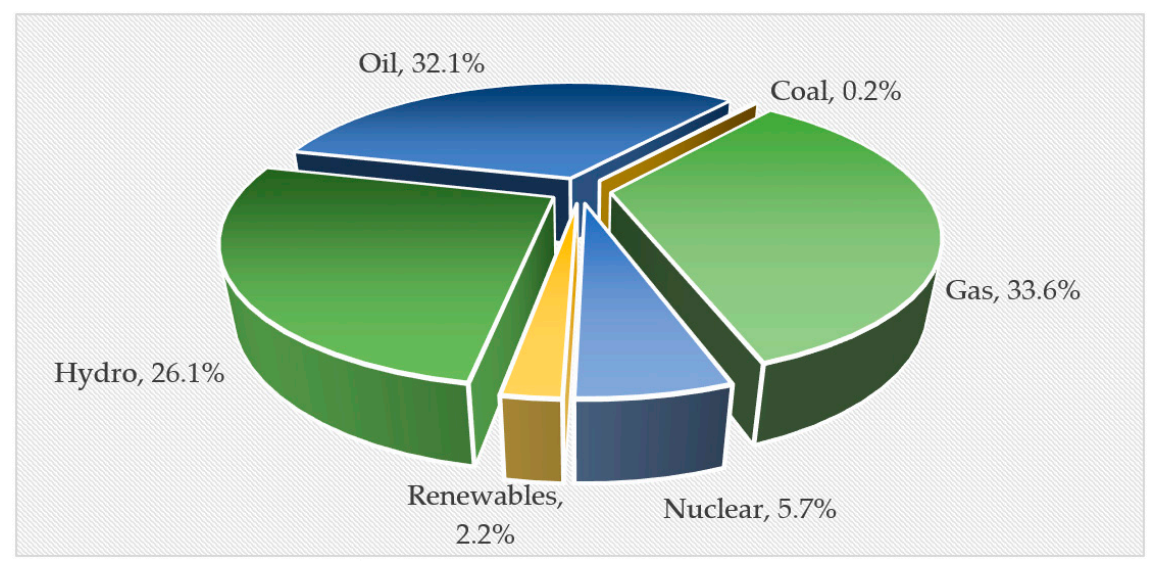

Figure 2. Energy mix of Pakistan.

The Sindh province is rich with renewable energy (RE) sources, such as wind, solar, mini-hydro, and biomass which could be easily utilized for electricity generation. However, the government of Sindh has not taken issues for the development of RE sources seriously, despite increasing demand for electricity. The government had planned a RE policy in 2006, but it is in the infancy stage due to the lack of interest of the government in exploiting these natural resources. Investors are worried and unwilling to invest in the remote rural regions of Sindh since a worse law and order situation, no infrastructure, and a low return on investment are the key factors behind obstructing private investment. However, recently the World Bank has announced that they will finance $\$ 100$ million worth of loans for the installation of clean energy in Sindh, the target is to provide off-grid solar PV electricity to 200,000 households, equal to 1.2 million people [30].

Therefore, this study will help government, policymakers, and stakeholders in the implementation of solar PV projects in the rural regions of Sindh.

\subsection{Solar PV Power Generation Progress in Remote Rural Regions}

Pakistan has installed a small number of solar PV projects in the country, and the first solar PV project was installed in the 1980s. However, the project failed due to the lack of managerial and to technical mistakes [33]. Afterward, until 2005, the country did not develop and promote any RE-based project. Later in 2006, two organizations were established, the Alternative Energy Development Board (AEDB) and the Pakistan Commission of Renewable Energy Technologies (PCRET) to promote and develop RE resources for electricity production [34]. AEDB intends to install a solar PV system in 906 houses of rural regions [35]. Furthermore, the government has understood the advantage of a solar energy framework for enriching socio-economic development and saving the environment in rural regions.

\subsection{Solar PV Power Generation Issues in Remote Rural Regions}

Solar PV is the appropriate option for providing electricity to off-grid rural regions because of the low-cost technology, easy installation and being environmentally benign. Whereas the development of the solar PV system is substantially very low in rural villages of Pakistan, according to the National Electric Power Regulatory Authority (NEPRA), 40,000 villages in the country do not have access to electricity [36]. There must be robust coordination among organizations is required for a successful solar PV rural electrification programs [37]. Before 2006, no organization was established for developing and planning RE projects, PCRET and AEDB were established in 2006 to coordinate and develop plans for the installation of RE projects in Pakistan. Unfortunately, the progress of both organizations for the development of RE is very poor.

The government has failed to develop and plan innovate strategies and policies for the solar PV system in rural regions, and solar energy productions have failed to take-off, regardless of the 
electricity crisis in Pakistan [38]. The common users put themselves at risk by choosing a solar energy solution as an alternative energy. The high up-front cost is also an interruption in the development of solar PV technology. Moreover, the cost of solar PV is significantly higher compared to that in developed countries [31]. In the finance bill 2014-15, the government implemented a 32\% tariff on the import of solar PV panels, which results in the low progress of solar PV. Therefore, the government took its decision back and reduced tariffs on solar panels. Despite tariffs on solar inverters, tariffs on batteries are still existing with around 50\%. Additionally, the government failed to provide incentives to households on the installation of a solar PV system, which shows the lack of government policies for both investors and customers [39].

\section{Research Framework}

The research framework of the study has been divided into several sub-sections, which are briefly described as follows:

\subsection{Determining the Solar Energy Potential}

The average peak solar hours are used to identify and determine the solar irradiation in a particular region when the sunshine at its maximum value for a certain number of hours. The peak solar irradiation is $1 \mathrm{~kW} / \mathrm{m}^{2}$, the peak hours of sun are equal to the daily solar irradiation in $\mathrm{kWh} / \mathrm{m}^{2}$. For example, the daily solar array output can be projected to be $545 \mathrm{Wh}$, if we assume that a $100 \mathrm{Wp}$ solar array is installed in the Panoaqil region with an average solar irradiation of $5.45 \mathrm{kWh} / \mathrm{m}^{2} /$ day. Therefore, the annual energy output can be computed for monitoring the PV system performance by using the Equation (1) [40]:

$$
\begin{aligned}
\text { Annual energy output }\left(\frac{\mathrm{kWh}}{\mathrm{kWp}}\right) \\
=\text { Global inplane irradition }\left(\left(\mathrm{kWh} / \mathrm{m}^{2}\right) / \text { year }\right) \times \text { Performance ratio }
\end{aligned}
$$

\subsection{Solar Irradiation and Determining the Optimal Tilt Angle}

The solar irradiation is generally measured on a horizontal surface of the particular region. The direct solar irradiation received by a solar panel produces a high energy yield. Thus, usually solar panels are angle-tilted to enhance the efficiency of the solar irradiation, and it is necessary to maximize the solar energy yield to determine the optimal tilt angle [41]. The most effective way to increase and improve the solar energy yield is by using solar tracker, solar trackers help in providing maximum energy by changing the angle of solar panels. Nevertheless, solar trackers require high costs, and they utilize more energy for tracking [42]. Furthermore, these solar trackers are a multifaceted nature. Thus it is useless to install in remote rural regions. Consequently, it is more convenient and feasible to change the title angle of solar panels manually rather than installing solar trackers [43]. The various techniques have been employed to compute the ideal title angle of solar panels for exploiting the solar irradiance [44-46]. In this study, a titled horizontal surface obtains a direct beam, some irradiation is diffused, and some are absorbed, while some rays show off the ground, therefore the global horizontal irradiance on a tilted surface $I_{G}^{T}$ is described as:

$$
I_{G}^{T}=I_{B}^{T}+I_{D}^{T}+I_{R}^{T}
$$

where $I_{B}^{T}$ is a direct beam, $I_{D}^{T}$ is diffuse irradiation, and $I_{R}^{T}$ is reflected rays of solar energy on a tilted surface.

Let $G_{B}$ be the ratio for the average daily direct beam on a horizontal surface and average daily direct beam on a tilted surface, then $I_{B}^{T}$ can be altered as:

$$
I_{B}^{T}=I_{B} G_{B}
$$


where $G_{B}$ is a geometric parameter, thus the value depends upon the declination angle, horizontal tilt, surface azimuth, and latitude, respectively. Here, the extensively employed Liu and Jordan model [47] is utilized for computing $G_{B}$,

$$
G_{B}=\frac{\cos \left(L_{1}-T_{1}\right) \cdot \cos D s h \cdot \sin i_{s S}+i_{s s} \cdot \sin \left(L_{1}-T_{1}\right) \cdot \sin D s h}{\cos L_{1} \cdot \cos D s h \cdot \sin i_{s s}+i_{s S} \cdot \sin L_{1} D s h}
$$

where $L_{1}$ is the latitude, $T_{1}$ is the tilt angle, and $i_{s s}$ and $D$ sh are declining angles and the sunshine hours.

For clarity, suppose an isotropic distribution of diffused irradiation. Therefore, the diffused region upon the diffused irradiation on the horizontal surface and the horizontal tilt angle $\lambda$ :

$$
I_{D}^{T}=I_{D} \frac{(\cos (\lambda)+1)}{2} .
$$

Here, a property which is famous as albedo factor $\omega$. The range of albedo varies between 0.1 and 0.9 [48]. Thus the reflected beam can be computed as:

$$
I_{R}^{T}=\omega\left(I_{B}+I_{D}\right) \frac{(-\cos (\lambda)+1)}{2} .
$$

\subsection{The Economic Viability of Off-Grid Solar PV Power Generation System}

The economic feasibility of the off-grid solar PV power generation system in rural regions can be described and identified in the following sub-sections:

\subsubsection{Solar PV Power Generation System Size and Battery Storage}

A normal solar PV system comprises a solar PV module, load or demand, battery storage, system controller, and DC-AC inverter. The solar PV panels receive solar energy and transfer it to the system controller, then transforming it to DC. Afterward, DC transmits the load to the DC and AC inverter. The electricity produced by a solar PV system relies on the solar irradiance obtained in a particular region. Whereas, several other criteria should be well-measured, such as optimal tilt, efficiency, and solar PV maintenance [49].

Moreover, it is essential to calculate the losses suffered during the DC-AC transformation. The various methods are available to forecast solar power yield on a tilted solar PV. The potential of solar PV to produce electricity and $S_{p v}(\mathrm{kWh})$ is computed using Equation (7) [50].

$$
S_{p v}=a_{p v} \cdot b_{p v} \cdot c_{t} \cdot P R
$$

where, $a_{p v}$ is the panel area, $b_{p v}$ is the efficiency, $c_{t}$ is the annual solar irradiation obtained on a tilted PV panel, and $P R$ is the performance ratio used to determine the losses. Further, $b_{p v}$ is computed as [51]:

$$
b_{p v}=b_{r}\left[1-\lambda_{r}\left[T_{A}-T_{R}+\left(T_{N}-T_{a . N}\right) \frac{I_{T}}{I_{N}}\right.\right.
$$

where $b_{r}$ is the efficiency of solar panels, $\lambda_{r}$ is the temperature of solar panels, $T_{A}$ is the ambient temperature and $T_{R}$ is the referenced temperature of solar panels, $T_{N}$ is the nominal operating temperature of solar panel cell, $T_{a . N}$ is the ambient nominal operating temperature, and $I_{N}$ is the solar radiation.

The designing of any solar PV is a very crucial task because it would have to approximate the load that the PV system supports. For any Solar PV, it is necessary to measure the demand of electricity per household, and it can be computed by multiple appliances, i.e., watt ratings, the number of operating hours, and summing up watt ratings. As presented in Table 1, the projected load is about $440 \mathrm{~W}$ per household in rural regions, comprising one pedestal fan, one ceiling fan, two charging slots, and three light-emitting diodes (LED) lights. 
Table 1. Projected load requirement per household.

\begin{tabular}{ccccc}
\hline Appliance & No. in Use & Operational Hours & Watts Rating & Total Load (Watts-Hour) \\
\hline Pedestal fan & 1 & 8 & 12 & 96 \\
Ceiling fan & 1 & 12 & 12 & 144 \\
Charging slot & 2 & 2 & 5 & 20 \\
LED light & 3 & 5 & 12 & 180 \\
\hline \multicolumn{7}{c}{ Total Watts per day } & 440 \\
\hline
\end{tabular}

The front end of the solar PV total electricity produced and demanded is presented here:

$$
\text { Electricity difference }=\sum_{i=1}^{365}\left(S_{p v}-S_{d}\right)
$$

where $i$ is the day of the year, $S_{p v}$ is the total electricity produced, and $S_{d}$ is the total electricity demand.

The solar energy can be used in the sunshine hours, thus for the night hours, an energy storage technology is required for providing the electricity to the households. Most of the remote rural regions of Sindh are off-grid, thus, battery storage is required at an extra cost. The benefit of battery storage is that the electricity can be stored in the battery and can be utilized anytime, mostly in night hours or cloudy weather when sunshine is unavailable. If electricity produced is more than its demand, then there will be an electricity surplus, such as $S_{p v}>S_{d}$, and the additional energy will be kept in the battery. However, if the demand of the electricity is more than the electricity produced then $S_{d}>S_{p v}$ and the solar PV is supposed to be insufficient to meet the electricity demand and load at a particular period. The electricity required to be saved in a battery annually, $K_{b}$, is therefore:

$$
K_{b}=\left(\sum S E-\sum F E\right) \cdot e_{b}
$$

where $S E$ is surplus electricity, $F E$ is shortfall electricity, and $e_{b}$ is the efficiency of the battery. Simultaneously, the daily storage capacity of a battery, $S_{b}$, is considered as:

$$
S_{b}=\frac{K_{b}}{365}
$$

\subsubsection{Levelized Cost of Electricity (LCOE)}

Levelized cost of electricity (LCOE) is an important metric employed to determine and compare the cost of electricity produced by several technologies and sources. It prioritizes numerous choices dependent on cost-effectiveness. This study compared the electricity generated by the off-grid solar PV system and a conventional on-grid system to determine the total cost of electricity in both systems. Therefore, the study has compared both alternative technologies through the estimated levelized cost of electricity in $\mathrm{kWh}$ unit and is computed by a simple LCOE formula [52]:

$$
L C O E=\frac{\sum_{\alpha=1}^{n} \frac{I_{\alpha}+M_{\alpha}+F_{\alpha}}{(1+d)^{\alpha}}}{\sum_{\alpha=1}^{n} \frac{e_{\alpha}}{(1+d)^{\alpha}}}
$$

where, $I_{\alpha}$ is the investment cost, $M_{i}$ is the maintenance cost, $F_{i}$ is the fuel cost, $\alpha$ is a year, $e_{i}$ is the amount of electricity generated in $\mathrm{kWh}, d$ is the discounted rate, and $n$ shows the working-life duration of the alternative technology.

\section{4. $\mathrm{CO}_{2}$ Emissions Mitigation from Solar PV Power Generation System}

The clean energy is generated from the solar PV system through sunlight, which may help to support minimizing greenhouse gas (GHG) emissions. Therefore, the government should install a 
solar PV system in the rural regions, so it may also help to eliminate the use and the need of diesel generators which may possess high-carbon intensity and affect the environment and human health in a bad manner. The solar PV system generates very little or no $\mathrm{CO}_{2}$ emissions during operation, but suffer emissions in the manufacturing period [53]. Environmental sustainability is a globally challenging issue since $\mathrm{CO}_{2}$ emissions are increasing from the unwanted activities of humans, such as utilizing fossils fuels, which may directly affect the climate in a bad manner [54,55]. Thus, a solar PV system can significantly mitigate $\mathrm{CO}_{2}$ emissions if it is replaced with a diesel generator. The amount of mitigating $\mathrm{CO}_{2}$ emissions and diesel fuel kept or saved, $F_{k}$, is calculated by employing a solar PV system [56]:

$$
F_{k}=S_{p v} \times F_{R}
$$

where $F_{R}$ is fuel required for a diesel generator for producing electricity of $1 \mathrm{kWh}$. For the solar PV system, the decrease in $\mathrm{CO}_{2}$ is measured in kilograms $(\mathrm{kg})$, the $\mathrm{CO}_{2}$ emissions kept or saved is $E M_{k}$ in the following Equation [56]:

$$
E M_{k}=S_{p v} \times\left(C_{d}-C_{p v}\right)
$$

where $C_{d}$ is the emitted carbon in $\mathrm{kg}$ required for a diesel generator for producing $1 \mathrm{kWh}$ of electricity, and $C_{p v}$ is the emitted carbon in $\mathrm{kg}$ required for a solar PV system to produce electricity of $1 \mathrm{kWh}$.

\section{Results and Discussion}

The most important step before implementing and utilizing a solar PV system is the determination of the available solar energy in the considered region [57]. The daily solar irradiance values received in all of the five rural regions present the appropriate potential to generate electricity from solar PV energy. Data of solar irradiance is obtained from the NASA database [58]. The data of these five regions, i.e., Panoaqil, Badin, Nawabshah, Mirpurkhas, and Kambar regions, has been provided in Table 2. It is identified from Table 2 that all of the selected remote rural regions have enough daily solar irradiation throughout the year for electricity generation. Further, the daily solar irradiation received on a horizontal surface in each rural region is presented in Figures 3-7. Moreover, the average values of annual solar irradiation in the selected rural regions of Sindh is illustrated in Figure 8. The Nawabshah region receives the highest annual solar irradiation $\left(5.49 \mathrm{kWh} / \mathrm{m}^{2}\right)$ followed by the Kambar region $\left(5.48 \mathrm{kWh} / \mathrm{m}^{2}\right)$, the Panoaqil region $\left(5.45 \mathrm{kWh} / \mathrm{m}^{2}\right)$, the Mirpurkhas region $\left(5.41 \mathrm{kWh} / \mathrm{m}^{2}\right)$, and the Badin region $\left(5.39 \mathrm{kWh} / \mathrm{m}^{2}\right)$, respectively.

\begin{tabular}{|c|c|c|c|c|c|c|c|c|c|c|}
\hline \multirow{2}{*}{ Period } & \multicolumn{2}{|c|}{ Panoaqil Region } & \multicolumn{2}{|c|}{$\begin{array}{l}\text { Badin } \\
\text { Region }\end{array}$} & \multicolumn{2}{|c|}{$\begin{array}{l}\text { Nawabshah } \\
\text { Region }\end{array}$} & \multicolumn{2}{|c|}{$\begin{array}{l}\text { Mirpurkhas } \\
\text { Region }\end{array}$} & \multicolumn{2}{|c|}{$\begin{array}{l}\text { Kambar } \\
\text { Region }\end{array}$} \\
\hline & $\begin{array}{l}\text { Daily Solar Irradiation } \\
\left(\mathrm{kWh} / \mathrm{m}^{2} / \text { day }\right)\end{array}$ & $\begin{array}{c}\text { Earth Temp } \\
\left({ }^{\circ} \mathrm{C}\right)\end{array}$ & - & - & - & - & - & - & - & - \\
\hline Jan & 4.10 & 14.65 & 4.49 & 16.92 & 4.20 & 14.60 & 4.41 & 15.90 & 3.73 & 14.70 \\
\hline Feb & 4.97 & 18.36 & 5.25 & 21.03 & 5.09 & 18.30 & 5.06 & 20.03 & 4.89 & 19.26 \\
\hline Mar & 5.71 & 25.29 & 5.97 & 27.85 & 5.76 & 26.19 & 5.88 & 27.55 & 5.83 & 26.04 \\
\hline April & 6.65 & 33.15 & 6.69 & 33.97 & 6.67 & 34.04 & 6.61 & 34.81 & 6.90 & 34.14 \\
\hline May & 6.88 & 38.72 & 6.79 & 36.06 & 6.90 & 37.55 & 6.78 & 37.81 & 6.79 & 39.60 \\
\hline June & 6.76 & 41.93 & 6.48 & 37.31 & 6.75 & 39.46 & 6.55 & 39.29 & 6.77 & 41.12 \\
\hline July & 5.91 & 40.69 & 5.08 & 36.15 & 5.82 & 37.91 & 5.52 & 37.94 & 5.65 & 39.92 \\
\hline Aug & 5.97 & 39.28 & 5.14 & 34.38 & 5.91 & 37.44 & 5.49 & 36.73 & 6.00 & 39.40 \\
\hline Sep & 5.86 & 39.28 & 5.47 & 33.45 & 5.82 & 35.75 & 5.58 & 34.95 & 5.82 & 36.01 \\
\hline Oct & 4.95 & 30.42 & 4.97 & 31.47 & 5.03 & 30.88 & 5.00 & 31.51 & 5.47 & 30.02 \\
\hline Nov & 4.00 & 22.97 & 4.31 & 26.55 & 4.13 & 24.37 & 4.15 & 25.67 & 4.22 & 21.03 \\
\hline Dec & 3.70 & 16.08 & 4.02 & 19.24 & 3.80 & 16.90 & 3.90 & 18.48 & 3.68 & 15.23 \\
\hline $\begin{array}{l}\text { Avg. } \\
\text { annual values }\end{array}$ & 5.45 & 30.06 & 5.39 & 29.53 & 5.49 & 29.45 & 5.41 & 30.05 & 5.48 & 29.71 \\
\hline
\end{tabular}

Table 2. Solar data for five regions of Sindh, Pakistan [58]. 


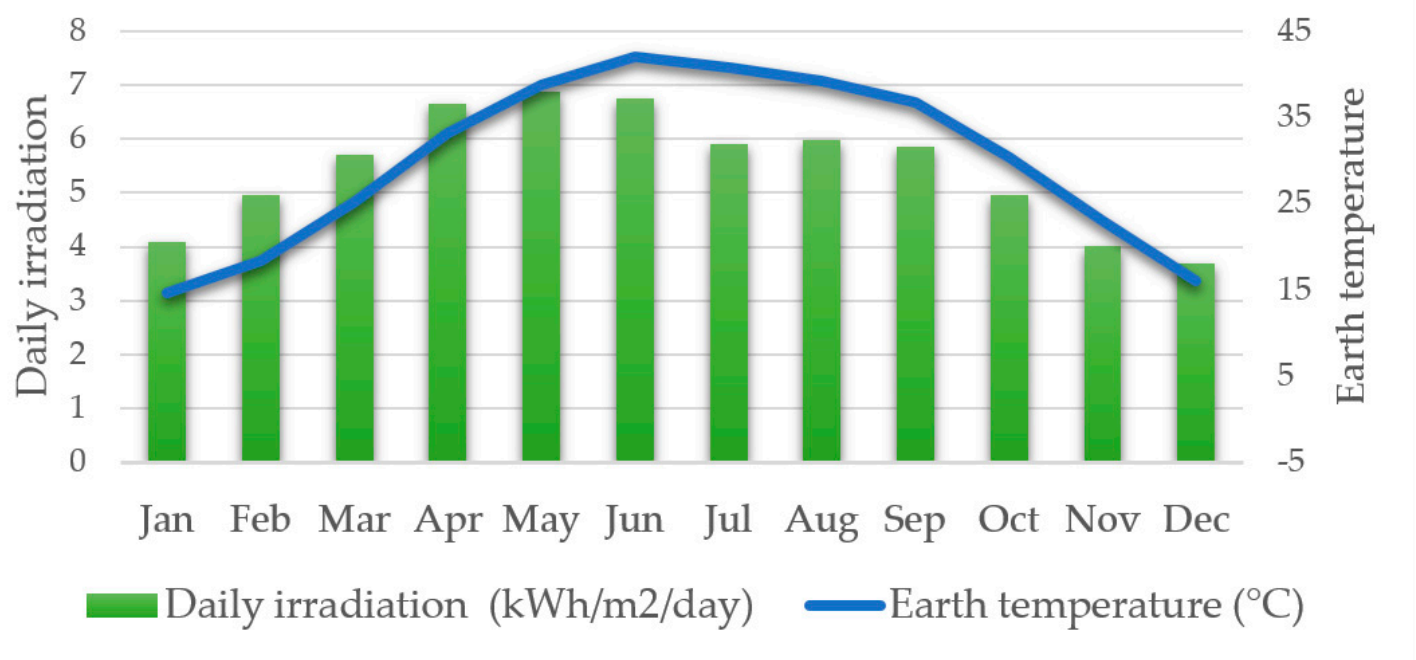

Figure 3. The Panoaqil region daily solar irradiance received.

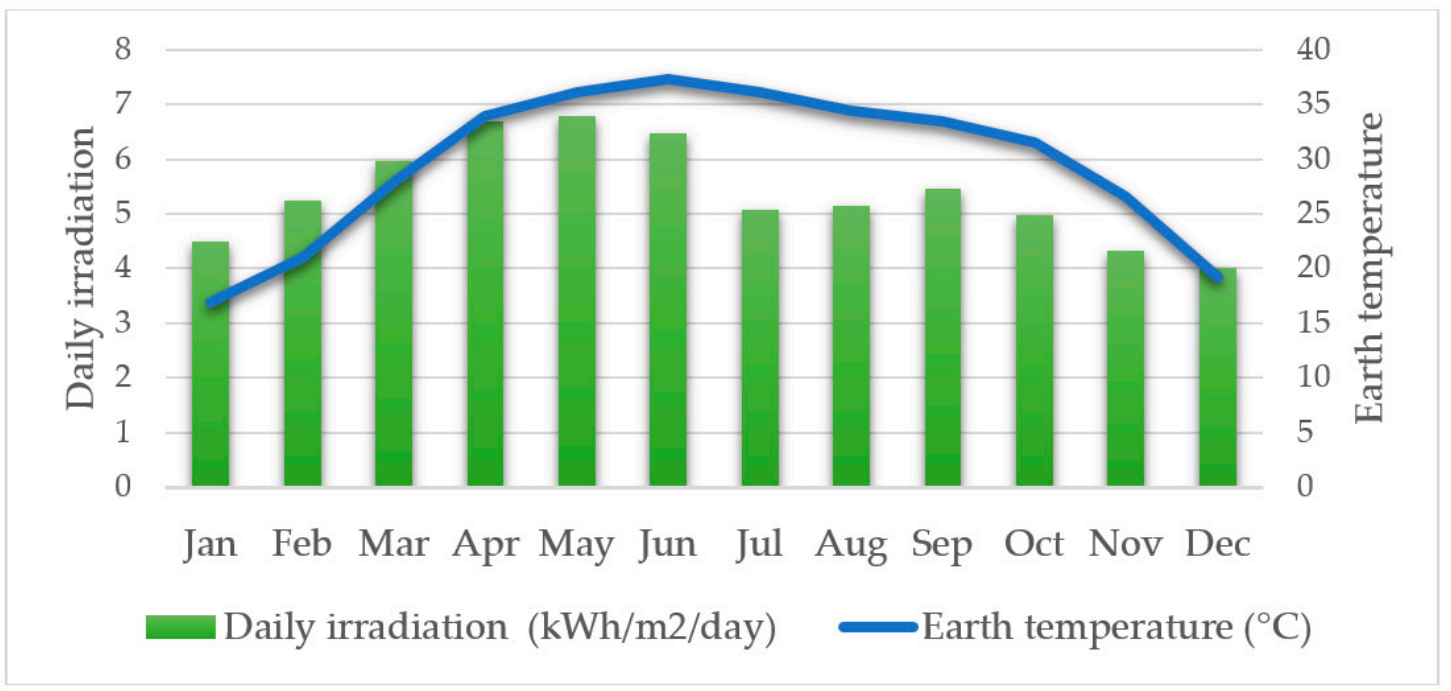

Figure 4. The Badin region daily solar irradiance received.

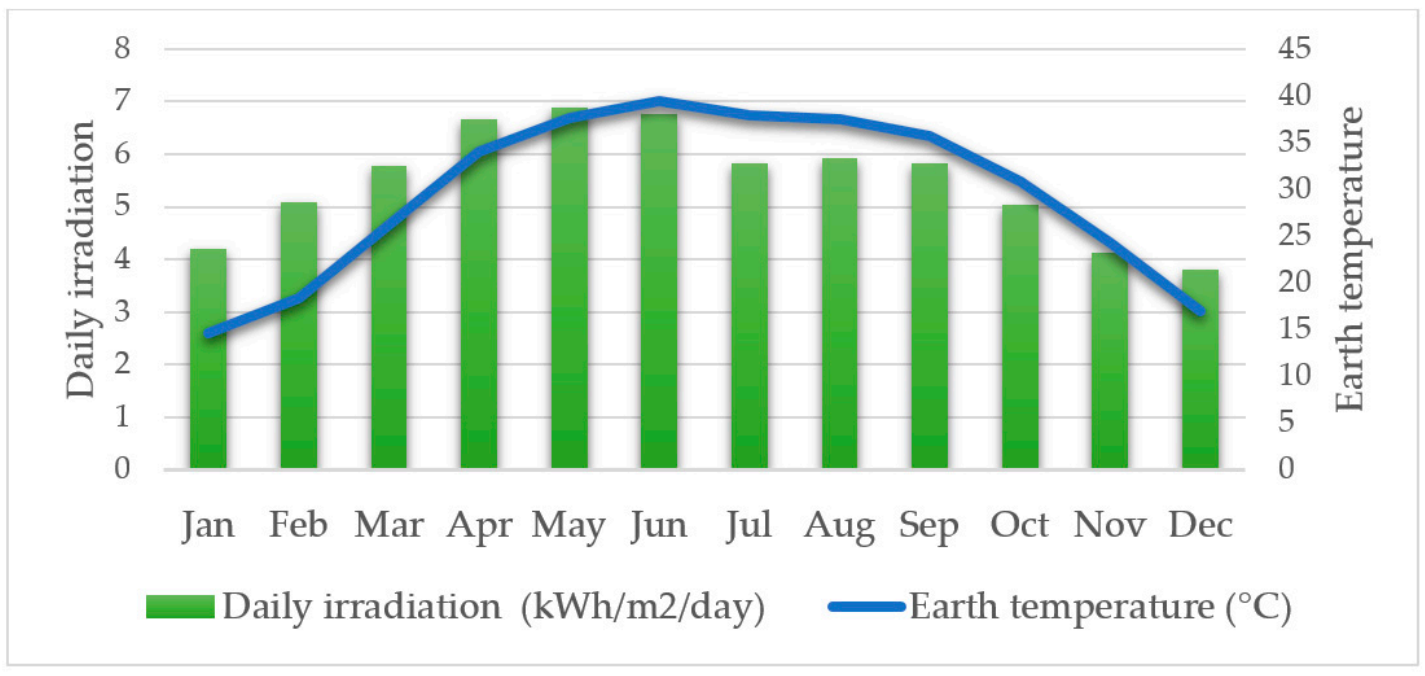

Figure 5. The Nawabshah region daily solar irradiance received. 


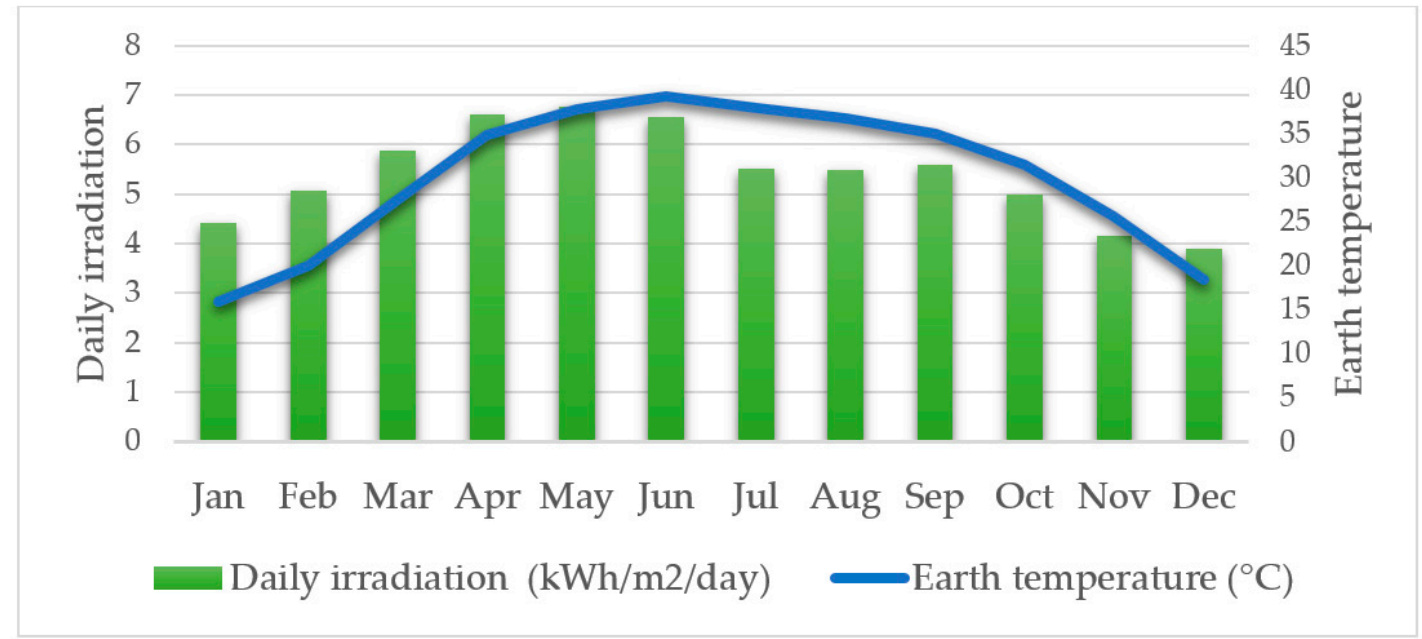

Figure 6. The Mirpurkhas region daily solar irradiation received.

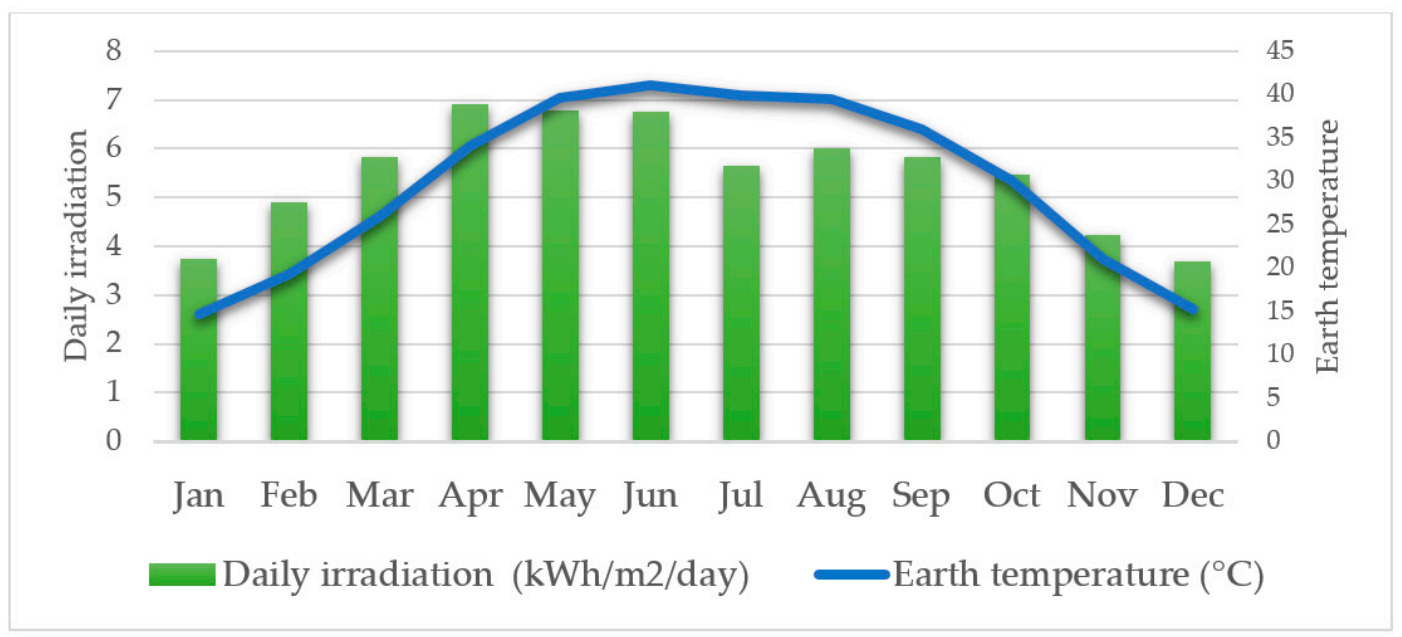

Figure 7. The Kambar region daily solar irradiation received.

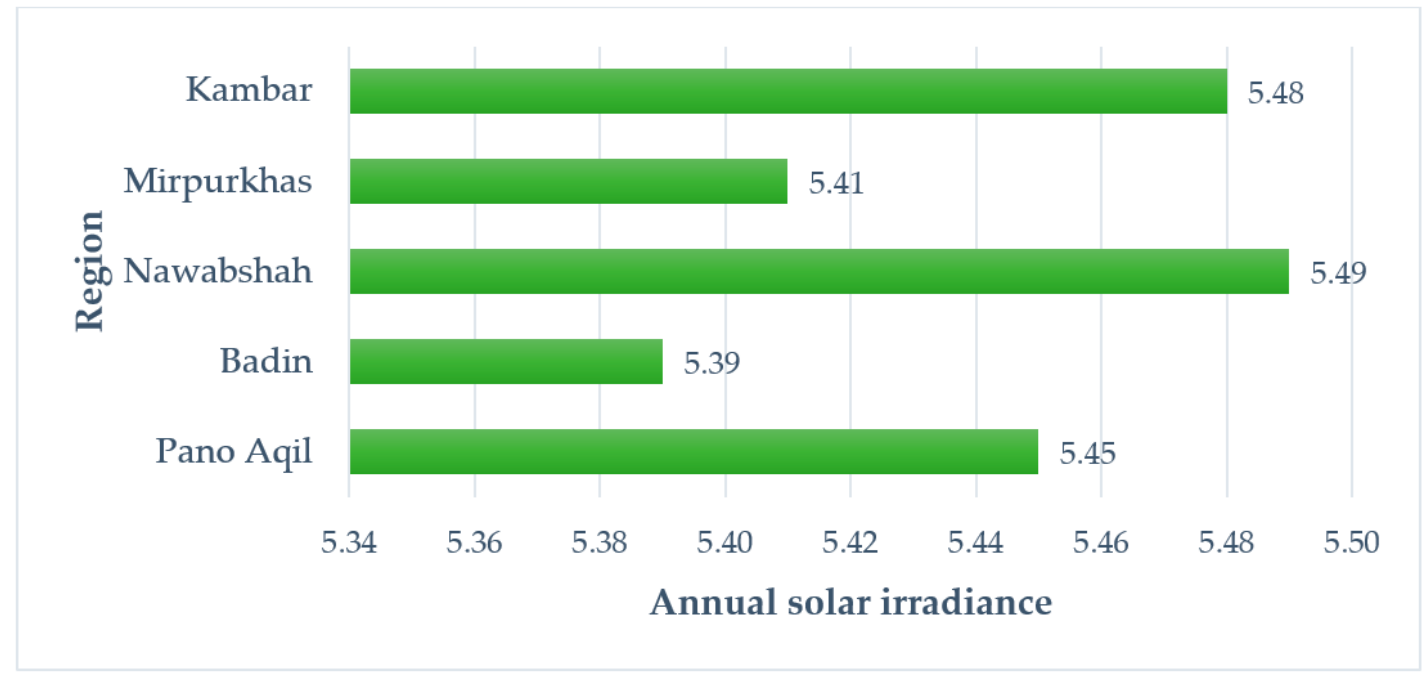

Figure 8. Annual solar irradiance received in five rural regions of Sindh.

\subsection{Analyzing the Solar Energy Potential}

The above-stated Figures present the average solar irradiation values for the selected regions of the Sindh province. The optimal average peak solar hours are also computed for the selected 
regions. Table 3 presents the total potential of using solar PV system in five regions of Sindh province, Pakistan, such as the Panoaqil, Badin, Nawabshah, Mirpurkhas, and Kambar regions. It presents that the potential for the solar PV power generation system is significant in these regions. For example, the Nawabshah and Kambar regions, with average solar irradiation of around $5.49 \mathrm{kWh} / \mathrm{m}^{2} /$ day and $5.48 \mathrm{kWh} / \mathrm{m}^{2} /$ day, have the probability of generating $1503 \mathrm{kWh} / \mathrm{kWp}$ and $1500 \mathrm{kWh} / \mathrm{kWp}$ annually. Furthermore, the daily energy produced from a solar PV panel is around more than $500 \mathrm{Wh}$ in each region of the Sindh province, which can satisfy the need for a primary household energy consumption.

Table 3. Potential of solar photovoltaic (PV) power generation in selected regions of Sindh, Pakistan.

\begin{tabular}{ccccc}
\hline Region & $\begin{array}{c}\text { Solar Irradiation } \\
\left(\mathbf{k W h} / \mathbf{m}^{\mathbf{2}} \mathbf{\text { day }}\right)\end{array}$ & $\begin{array}{c}\text { Avg. Peak } \\
\text { Solar Hours }\end{array}$ & $\begin{array}{c}\text { Daily Energy } \\
\text { Output } \mathbf{( W h )}\end{array}$ & $\begin{array}{c}\text { Annual Energy Output } \\
\mathbf{( k W h / k W \mathbf { p } )}\end{array}$ \\
\hline Panoaqil & 5.45 & 5.450 & 545 & 1492.21 \\
Badin & 5.39 & 5.390 & 539 & 1475.782 \\
Nawabshah & 5.49 & 5.490 & 549 & 1503.162 \\
Mirpurkhas & 5.41 & 5.410 & 541 & 1481.258 \\
Kambar & 5.48 & 5.480 & 548 & 1500.424 \\
\hline
\end{tabular}

\subsection{Solar Irradiation Obtained at the Optimal Tilt Angle}

Using Equations (2)-(6), the mean values of daily solar irradiation received on a tilted angle are shown in Table 4. Similarly, [59] we conducted the techno-economic analysis to check the impact of title angle on the performance of a PV battery storage for a single household in Germany. The results indicate that a substantial percentage of solar energy yield can be annually elevated by changing the angle from 0 to 90 degrees of solar PV panels on the optimal tilt angle. Solar energy yield can be elevated by $9.87 \%$ in Panoaqil at the optimal tilt angle of $28.9^{\circ}$. Likewise, $9.98 \%$ in Badin on $29.1^{\circ}$, $10.11 \%$ in Nawabshah on $29.3^{\circ}, 11.66 \%$ in Mirpurkhas on $30.6^{\circ}$, and $10.43 \%$ in Kambar at $29.5^{\circ}$.

Table 4. Daily solar irradiation $\left(\mathrm{kWh} / \mathrm{m}^{2} /\right.$ day) received on a tilted varying between 0 and 90 angle degrees.

\begin{tabular}{cccccccc}
\hline Region & $\begin{array}{c}\text { 0 Tilt } \\
\text { Angle } \\
\text { Degree }\end{array}$ & $\begin{array}{c}\text { 15 Tilt } \\
\text { Angle } \\
\text { Degree }\end{array}$ & $\begin{array}{c}\text { 30 Tilt } \\
\text { Angle } \\
\text { Degree }\end{array}$ & $\begin{array}{c}\text { 45 Tilt } \\
\text { Angle } \\
\text { Degree }\end{array}$ & $\begin{array}{c}\text { 60 Tilt } \\
\text { Angle } \\
\text { Degree }\end{array}$ & $\begin{array}{c}\text { 75 Tilt } \\
\text { Angle } \\
\text { Degree }\end{array}$ & $\begin{array}{c}\text { 90 Tilt } \\
\text { Angle } \\
\text { Degree }\end{array}$ \\
\hline Panoaqil & 5.8 & 6.2 & 6.3 & 6.1 & 5.6 & 4.8 & 3.9 \\
Badin & 5.5 & 5.9 & 6.0 & 5.8 & 5.4 & 4.6 & 3.7 \\
Nawabshah & 5.7 & 6.2 & 6.3 & 6.2 & 5.7 & 4.9 & 4.0 \\
Mirpurkhas & 5.8 & 6.2 & 6.3 & 6.1 & 5.6 & 4.8 & 3.9 \\
Kambar & 5.8 & 6.2 & 6.3 & 6.1 & 5.6 & 4.8 & 3.9 \\
\hline
\end{tabular}

\subsection{The Economic Viability of Solar PV Power Generation System}

An off-grid solar PV system is proposed in the study to provide electricity to rural households in the Sindh province. In Table 5, the simulation of the parameters has been employed and provided by [60]. Based on Equations (7)-(11), it is identified that the PV module area is $1.2 \mathrm{~m}^{2}$, whereas maximum voltage and current are $26.3 \mathrm{~V}$ and 7.61 A. The solar PV system can be used for the electrification of one household, having a production capacity of $200 \mathrm{~W}$ or less [61]. Therefore, for a solar panel of $200 \mathrm{~W}$ with a $140 \mathrm{Ah} / 12 \mathrm{~V}$ battery is appropriate for the load of one household. Moreover, the conversion efficiency of a solar panel is $16 \%$. Maximum electricity is produced in all of the selected rural regions from April to June, however, due to monsoon season, a slight decline is observed from July to October in the rural regions of Sindh. The cost specifications for the off-grid solar PV system are shown in Table 5. It was identified using Equation (12), that the levelized cost of energy (LCOE) of the proposed off-grid solar PV system is PKR 6.87/kWh, however, the electricity cost from the conventional energy sources is PKR 20.79/kWh [60]. Thus, electricity produced by the solar PV system saves each household approximately PKR 13.92 per kWh. 
Table 5. Parameters employed in the study.

\begin{tabular}{ccc}
\hline Parameter & Unit & Value \\
\hline Panel area & $\mathrm{m}^{2}$ & 1.2 \\
Max: power current & $\mathrm{A}$ & 7.61 \\
Max: power voltage & $\mathrm{V}$ & 26.3 \\
PV panel power rating & $\mathrm{WP}$ & 200 \\
Ambient temperature & ${ }^{\circ} \mathrm{C}$ & 20 \\
Panel referenced temperature & ${ }^{\circ} \mathrm{C}$ & 25 \\
Panel referenced efficiency & $\%$ & 16 \\
Solar radiation for NOM & $\mathrm{W} / \mathrm{m}^{2}$ & 800 \\
PV panel life & Year & 25 \\
Panel capital cost & PKR/WP & 110 \\
Battery efficiency & $\%$ & 85 \\
Battery cost & PKR/Ah & 120 \\
O/M cost & $\%$ of the total cost & 4 \\
Discount rate & $\%$ & 9 \\
Battery duration & Year & 5 \\
\hline
\end{tabular}

\section{4. $\mathrm{CO}_{2}$ Emissions Mitigation from the Solar PV Power Generation System}

A $20 \mathrm{~kW}$ diesel generator produces the electricity of $4 \mathrm{kWh} / \mathrm{liter}$. The annual demand of the electricity for the household mentioned above is $160 \mathrm{kWh}$, so the diesel generator would consume a total of $41.43 \mathrm{~L} /$ year. Therefore, based on Equation (14), as per household, the proposed solar PV system could mitigate $\mathrm{CO}_{2}$ at about $97.50 \mathrm{~kg} /$ year. According to the sixth population and housing census of Pakistan, there are 4,185,828 households in rural regions of Sindh [62]. If the off-grid solar PV system electrified $100 \%$ of the rural areas, then the high level of $\mathrm{CO}_{2}$ could be mitigated annually.

\section{Conclusions and Policy Recommendations}

\subsection{Conclusions}

An off-grid solar PV system is recognized as the optimal choice to provide electricity in remote rural regions. However, it is very necessary to assess the techno-economic feasibility of the particular region for installation of an off-grid solar PV power generation system. Therefore, this study has evaluated the techno-economic feasibility of five rural regions of the Sindh province, i.e., the Panoaqil, Badin, Nawabshah, Mirpurkhas, and Kambar regions. The study also suggests that by installing the off-grid solar PV system in the above-mentioned regions it would help to mitigate the $\mathrm{CO}_{2}$ emissions from the particular regions. The solar energy potential, solar irradiance, and optimal tile angles of solar panels have been evaluated. For maximizing the solar energy, it was found that the output of energy could be significantly increased by varying the solar panels angle on the optimal tilt angle. The results also revealed that the off-grid solar PV system is a much cheaper option for electricity compared to other conventional electricity sources. This study identified that all five regions of the Sindh province have good potential for solar energy and are technically and economically feasible for producing electricity. Therefore, the government must plan and build a strong policy framework to install an off-grid solar system in the Sindh province. Meanwhile, this study provides key policy recommendations for the implementation of an off-grid solar PV system in the rural regions of Sindh.

\subsection{Policy Recommendations}

The following policy recommendations can be employed to develop an off-grid solar PV power generation system in remote rural regions of the Sindh province, Pakistan.

- The results of this study indicate that rural regions have a very good potential for solar-based electricity generation. Therefore, off-grid solar PV rural programs must be started with critical 
action plans and strategies and the concerned authorities must formulate planning and policies to implement such projects.

- According to the investigation, all of the selected regions have suitable solar energy potential to generate off-grid solar PV electricity. However, the Nawabshah is the most favorable due to its higher solar energy potential. Also, the geographical location of Nawabshah is technically and economically the best option for generating PV electricity.

- As the review of the existing scientific studies and government policies indicate, lack of supportive policies and political will are the main hurdles in the deployment of solar electricity generation systems in rural areas of the country $[63,64]$.

- It is suggested that supportive policies must be planned for stakeholders so that stakeholders can easily invest in rural regions for developing a solar PV power generation system.

- The financial constraints due to poverty and a huge budget deficit are also recognized as another hurdle in the deployment of the solar PV system. Therefore, the government tries to ensure the availability of micro-financing projects which may aid rural communities to install an off-grid solar PV system.

- The policy framework should be formulated by giving high preference to a renewable-based solar power system instead of the conventional power generation system.

- The upfront cost of a solar PV system must be minimized, so that rural communities install and electrify with a solar PV system.

- The quality standards should be taken into account for the off-grid solar PV system.

- It is important that householders should be given loans and subsidies to utilize solar PV power generation systems at the domestic level.

- Educate people by organizing training and campaigns about the drawback associated with conventional energy and make them aware of the advantages related to the deployment of solar energy.

- Priority must be given to the local communities and train them to install, operate, and maintain the solar PV system.

\subsection{Limitations of the Current Study and Future Research Direction}

This study has considered only five particular regions of Sindh province, thus the results of the study are not feasible for other regions of Sindh and other provinces of Pakistan. Therefore, the techno-economic feasibility analysis must be carried out for other regions to identify solar power potential. In the future, the hybrid renewable energy system, solar and wind, can be developed in the potential regions of Pakistan because the hybrid renewable energy system is a more reliable and effective source of energy. The hybrid solar-wind energy system shall be employed in the remote rural regions of Pakistan to make them independent of grids. The government can play a pivotal role to end the energy crisis by facilitating rural regions with such a hybrid energy system.

Author Contributions: Conceptualization, Y.A.S., S.A.A.S.; methodology, L.X.; Y.W., Y.A.S. and S.A.A.S.; validation, S.A.A.S.; H.Z.; formal analysis, L.X.; Y.A.S.; and H.Z.; writing-original draft preparation, L.X.; Y.W.; and H.Z.; writing-review and editing, Y.W., H.Z.; and Y.A.S.; funding acquisition, Y.W.

Funding: 1. National Natural Science Foundation of China (Grant No. 71873064), Research on OFDI driving low-carbon upgrading of China's equipment manufacturing global value chain: theoretical mechanism, implementation path, and performance evaluation. 2. General Projects of Humanities and Social Sciences of the Ministry of Education (Planning Projects) (Grant No. 18YJA790085), Performance evaluation of OFDI driving low-carbon upgrading of China's equipment.

Acknowledgments: These data of Table 2 were obtained from the NASA Langley Research Center (LaRC) POWER Project funded through the NASA Earth Science/Applied Science Program.

Conflicts of Interest: The authors declare that there is no conflict of interest regarding the publication of this paper. 


\section{References}

1. Warner, K.J.; Jones, G.A. A Population-Induced Renewable Energy Timeline in Nine World Regions. Energy Policy 2017, 101, 65-76. [CrossRef]

2. International Energy Agency (IEA). World Energy Outlook 2017; International Energy Agency: Paris, France, 2017; pp. 1-15.

3. Rehman, S.A.U.; Cai, Y.; Fazal, R.; Das Walasai, G.; Mirjat, N.H. An Integrated Modeling Approach for Forecasting Long-Term Energy Demand in Pakistan. Energies 2017, 10, 1868. [CrossRef]

4. Raheem, A.; Abbasi, S.A.; Memon, A.; Samo, S.R.; Taufiq-Yap, Y.H.; Danquah, M.K.; Harun, R. Renewable Energy Deployment to Combat Energy Crisis in Pakistan. Energy Sustain. Soc. 2016, 6, 16. [CrossRef]

5. Mirjat, N.H.; Uqaili, M.A.; Harijan, K.; Das Valasai, G.; Shaikh, F.; Waris, M. A Review of Energy and Power Planning and Policies of Pakistan. Renew. Sustain. Energy Rev. 2017, 79, 110-127. [CrossRef]

6. Solangi, Y.A.; Tan, Q.; Mirjat, N.H.; Das Valasai, G.; Khan, M.W.A.; Ikram, M. An Integrated Delphi-AHP and Fuzzy TOPSIS Approach toward Ranking and Selection of Renewable Energy Resources in Pakistan. Processes 2019, 7, 118. [CrossRef]

7. Dailytimes. Sindh is Resource-Rich Province, Govt only Needs to Tap Them, Says CM. Available online: https: //dailytimes.com.pk/317213/sindh-is-resource-rich-province-govt-only-needs-to-tap-them-says-cm/ (accessed on 25 April 2019).

8. Qayyum, S. Pakistan: A Renewable Energy State? Available online: http://www.technologyreview.pk/ pakistan-a-renewable-energy-state/ (accessed on 22 October 2018).

9. Bhutto, A.W.; Bazmi, A.A.; Zahedi, G. Greener Energy: Issues and Challenges for Pakistan-Solar Energy Prospective. Renew. Sustain. Energy Rev. 2012, 16, 2762-2780. [CrossRef]

10. Mirza, U.K.; Ahmad, N.; Harijan, K.; Majeed, T. Identifying and Addressing Barriers to Renewable Energy Development in Pakistan. Renew. Sustain. Energy Rev. 2009, 13, 927-931. [CrossRef]

11. DAWN. Sindh, KP Ask PM to Reverse Decisions about Renewable Energy. Available online: https: //www.dawn.com/news/1477631 (accessed on 25 April 2019).

12. Irfan, M.; Zhao, Z.-Y.; Ahmad, M.; Mukeshimana, M.C. Solar Energy Development in Pakistan: Barriers and Policy Recommendations. Sustainability 2019, 11, 1206. [CrossRef]

13. Wakeel, M.; Chen, B.; Jahangir, S. Overview of Energy Portfolio in Pakistan. Energy Procedia 2016, 88, 71-75. [CrossRef]

14. Hasnie, S. How the un-Electrified Poor can Leapfrog to Off-Grid Solar. Available online: https://blogs.adb. org/blog/how-unelectrified-poor-can-leapfrog-grid-solar (accessed on 6 April 2019).

15. Mamaghani, A.H.; Escandon, S.A.A.; Najafi, B.; Shirazi, A.; Rinaldi, F. Techno-Economic Feasibility of Photovoltaic, Wind, Diesel and Hybrid Electrification Systems for off-Grid Rural Electrification in Colombia. Renew. Energy 2016, 97, 293-305. [CrossRef]

16. Ghafoor, A.; Munir, A. Design and Economics Analysis of an Off-Grid PV System for Household Electrification. Renew. Sustain. Energy Rev. 2015, 42, 496-502. [CrossRef]

17. Sandwell, P.; Chan, N.L.A.; Foster, S.; Nagpal, D.; Emmott, C.J.M.; Candelise, C.; Buckle, S.J.; Ekins-Daukes, N.; Gambhir, A.; Nelson, J. Off-Grid Solar Photovoltaic Systems for Rural Electrification and Emissions Mitigation in India. Sol. Energy Mater. Sol. Cells 2016, 156, 147-156. [CrossRef]

18. Mishra, P.; Behera, B. Socio-Economic and Environmental Implications of Solar Electrification: Experience of Rural Odisha. Renew. Sustain. Energy Rev. 2016, 56, 953-964. [CrossRef]

19. Hosenuzzaman, M.; Rahim, N.A.; Selvaraj, J.; Hasanuzzaman, M.; Malek, A.B.M.A.; Nahar, A. Global Prospects, Progress, Policies, and Environmental Impact of Solar Photovoltaic Power Generation. Renew. Sustain. Energy Rev. 2015, 41, 284-297. [CrossRef]

20. Kerekes, T.; Koutroulis, E.; Séra, D.; Teodorescu, R.; Katsanevakis, M. An Optimization Method for Designing Large PV Plants. IEEE J. Photovolt. 2013, 3, 814-822. [CrossRef]

21. Islam, M.R.; Guo, Y.; Zhu, J. A Multilevel Medium-Voltage Inverter for Step-up-Transformer-Less Grid Connection of Photovoltaic Power Plants. IEEE J. Photovolt. 2014, 4, 881-889. [CrossRef]

22. Nasir, M.; Khan, H.A.; Hussain, A.; Mateen, L.; Zaffar, N.A. Solar PV Based Scalable DC Microgrid for Rural Electrification in Developing Regions. IEEE Trans. Sustain. Energy 2018, 9, 390-399. [CrossRef]

23. Wilson, M.; Luck, R.; Mago, P.; Cho, H. Building Energy Management Using Increased Thermal Capacitance and Thermal Storage Management. Buildings 2018, 8, 86. [CrossRef] 
24. Iqbal, W.; Yumei, H.; Abbas, Q.; Hafeez, M.; Mohsin, M.; Fatima, A.; Jamali, M.A.; Jamali, M.; Siyal, A.; Sohail, N. Assessment of Wind Energy Potential for the Production of Renewable Hydrogen in Sindh Province of Pakistan. Processes 2019, 7, 196. [CrossRef]

25. Awan, U.; Imran, N.; Muneer, G. Sustainable Development through Energy Management: Issues and Priorities in Energy Savings. Res. J. Appl. Sci. Eng. Technol. 2014, 7, 424-429. [CrossRef]

26. Govt. of Sindh. Population Welfare Department Sindh Population Welfare Department Sindh. Available online: http://pwdsindh.gov.pk/ (accessed on 8 January 2018).

27. Kazmi, S.A.Z.; Naaranoja, M.; Kantola, J. Reviewing Pakistan's Investment Potential as a Foreign Investor. Procedia Soc. Behav. Sci. 2016, 235, 611-617. [CrossRef]

28. Map, G. Sindh Map, Pakistan. Available online: https://www.google.com/maps/place/Sindh,+Pakistan/ (accessed on 25 April 2019).

29. Khalil, H.B.; Zaidi, S.J.H. Energy Crisis and Potential of Solar Energy in Pakistan. Renew. Sustain. Energy Rev. 2014, 31, 194-201. [CrossRef]

30. Bhutta, Z. Power Shortfall Hits Record Peak. Available online: https://tribune.com.pk/story/1742548/1electricity-deficit-power-shortfall-hits-record-peak/ (accessed on 22 October 2018).

31. Harijan, K.; Uqaili, M.; Mirza, U. Assessment of Solar PV Power Generation Potential in Pakistan. J. Clean Energy Technol. 2015, 3, 54-56. [CrossRef]

32. Hydrocarbon Development Institute of Pakistan. Pakistan Energy Yearbook; Hydrocarbon Development Institute of Pakistan: Islamabad, Pakistan, 2017.

33. Shaikh, P.H.; Shaikh, F.; Mirani, M. Solar Energy: Topographical Asset for Pakistan. Appl. Sol. Energy 2013, 49, 49-53. [CrossRef]

34. Solangi, Y.A.; Tan, Q.; Khan, M.W.A.; Mirjat, N.H.; Ahmed, I. The Selection of Wind Power Project Location in the Southeastern Corridor of Pakistan: A Factor Analysis, AHP, and Fuzzy-TOPSIS Application. Energies 2018, 11, 1940. [CrossRef]

35. AEDB. Progress so Far Made in Solar Power Sector in Pakistan. Available online: https://www.aedb.org/aetechnologies/solar-power/solar-current-status (accessed on 6 April 2019).

36. NEPRA. State of Industry Report 2016. Available online: http://www.nepra.org.pk/ (accessed on 6 April 2019).

37. Urmee, T.; Harries, D.; Schlapfer, A. Issues Related to Rural Electrification Using Renewable Energy in Developing Countries of Asia and Pacific. Renew. Energy 2009, 34, 354-357. [CrossRef]

38. Dawn. Solar Energy Production Fails to Take off Despite Electricity Crisis. Available online: https: //www.dawn.com/news/1194261 (accessed on 25 April 2019).

39. Bhutta, F.M. Solar PV Opportunities and Challenges in Pakistan. April 2015. Available online: http: //engghorizons.com/solar-pv-opportunities-and-challenges-in-pakistan/ (accessed on 6 April 2019).

40. Borhanazad, H.; Mekhilef, S.; Saidur, R.; Boroumandjazi, G. Potential Application of Renewable Energy for Rural Electrification in Malaysia. Renew. Energy 2013, 59, 210-219. [CrossRef]

41. Benghanem, M. Optimization of Tilt Angle for Solar Panel: Case Study for Madinah, Saudi Arabia. Appl. Energy 2011, 88, 1427-1433. [CrossRef]

42. Barker, L.; Neber, M.; Lee, H. Design of a Low-Profile Two-Axis Solar Tracker. Sol. Energy 2013, 97, 569-576. [CrossRef]

43. Shah, S.A.A.; Das Valasai, G.; Memon, A.A.; Laghari, A.N.; Jalbani, N.B.; Strait, J.L. Techno-Economic Analysis of Solar PV Electricity Supply to Rural Areas of Balochistan, Pakistan. Energies 2018, 11, 1777. [CrossRef]

44. Skeiker, K. Optimum Tilt Angle and Orientation for Solar Collectors in Syria. Energy Convers. Manag. 2009, 50, 2439-2448. [CrossRef]

45. Hartner, M.; Ortner, A.; Hiesl, A.; Haas, R. East to West-The Optimal Tilt Angle and Orientation of Photovoltaic Panels from an Electricity System Perspective. Appl. Energy 2015, 160, 94-107. [CrossRef]

46. Rowlands, I.H.; Kemery, B.P.; Beausoleil-Morrison, I. Optimal Solar-PV Tilt Angle and Azimuth: An Ontario (Canada) Case-Study. Energy Policy 2011, 39, 1397-1409. [CrossRef]

47. Liu, B.; Jordan, R. Daily Insolation on Surfaces Tilted towards Equator. ASHRAE Trans. 1962, 67, 526-541.

48. Kotak, Y.; Gul, M.S.; Muneer, T. Investigating the Impact of Ground Albedo on the Performance of PV Systems. In Proceedings of the CIBSE Technical Symposium, London, UK, 16-17 April 2015.

49. Stojanovski, O.; Thurber, M.; Wolak, F. Rural Energy Access through Solar Home Systems: Use Patterns and Opportunities for Improvement. Energy Sustain. Dev. 2017, 37, 33-50. [CrossRef] 
50. Okoye, C.O.; Oranekwu-Okoye, B.C. Economic Feasibility of Solar PV System for Rural Electrification in Sub-Sahara Africa. Renew. Sustain. Energy Rev. 2018, 82, 2537-2547. [CrossRef]

51. Okoye, C.O.; Taylan, O.; Baker, D.K. Solar Energy Potentials in Strategically Located Cities in Nigeria: Review, Resource Assessment and PV System Design. Renew. Sustain. Energy Rev. 2016, 55, 550-566. [CrossRef]

52. Baurzhan, S.; Jenkins, G.P. Off-Grid Solar PV: Is It an Affordable or Appropriate Solution for Rural Electrification in Sub-Saharan African Countries? Renew. Sustain. Energy Rev. 2016, 60, 1405-1418. [CrossRef]

53. Jabeen, M.; Umar, M.; Zahid, M.; Rehaman, M.U.; Batool, R.; Zaman, K. Socio-Economic Prospects of Solar Technology Utilization in Abbottabad, Pakistan. Renew. Sustain. Energy Rev. 2014, 39, 1164-1172. [CrossRef]

54. Ikram, M.; Mahmoudi, A.; Shah, S.Z.A.; Mohsin, M. Forecasting Number of ISO 14001 Certifications of Selected Countries: Application of Even GM (1,1), DGM, and NDGM Models. Environ. Sci. Pollut. Res. 2019, 26, 12505-12521. [CrossRef]

55. Ali, S.; Xu, H.; Ahmed, W.; Ahmad, N.; Solangi, Y.A. Metro Design and Heritage Sustainability: Conflict Analysis Using Attitude Based on Options in the Graph Model. Environ. Dev. Sustain. 2019, 1-22. [CrossRef]

56. Baurzhan, S.; Jenkins, G.P. On-Grid Solar PV versus Diesel Electricity Generation in Sub-Saharan Africa: Economics and GHG Emissions. Sustainability 2017, 9, 372. [CrossRef]

57. Kharseh, M.; Wallbaum, H. How Adding a Battery to a Grid-Connected Photovoltaic System Can Increase Its Economic Performance: A Comparison of Different Scenarios. Energies 2019, 12, 30. [CrossRef]

58. NASA-POWER Project Data Sets. Available online: https://power.larc.nasa.gov/ (accessed on 23 October 2018).

59. Lahnaoui, A.; Stenzel, P.; Linssen, J. Tilt Angle and Orientation Impact on the Techno-Economic Performance of Photovoltaic Battery Systems. Energy Procedia 2017, 105, 4312-4320. [CrossRef]

60. Ullah, H.; Kamal, I.; Ali, A.; Arshad, N. Investor Focused Placement and Sizing of Photovoltaic Grid-Connected Systems in Pakistan. Renew. Energy 2018, 121, 460-473. [CrossRef]

61. Abdullah; Zhou, D.; Shah, T.; Jebran, K.; Ali, S.; Ali, A.; Ali, A. Acceptance and Willingness to Pay for Solar Home System: Survey Evidence from Northern Area of Pakistan. Energy Rep. 2017, 3, 54-60. [CrossRef]

62. Pakistan Bureau of Statistics. 6th Population and Housing Census. Available online: http://www.pbs.gov.pk/ (accessed on 6 April 2019).

63. Zafar, U.; Ur Rashid, T.; Khosa, A.A.; Khalil, M.S.; Rahid, M. An Overview of Implemented Renewable Energy Policy of Pakistan. Renew. Sustain. Energy Rev. 2018, 82, 654-665. [CrossRef]

64. Zameer, H.; Wang, Y. Energy Production System Optimization: Evidence from Pakistan. Renew. Sustain. Energy Rev. 2018, 82, 886-893. [CrossRef]

(C) 2019 by the authors. Licensee MDPI, Basel, Switzerland. This article is an open access article distributed under the terms and conditions of the Creative Commons Attribution (CC BY) license (http://creativecommons.org/licenses/by/4.0/). 